\title{
Kinerja Rangkak pada Balok Beton Sandwich dengan Isian Styrofoam (Cement EPS Sandwich Panel)
}

\author{
Rilo Hanif Hasbi Ardin; Yohanna Ariesta; \\ Rr. M.I. Retno Susilorini dan David Widianto \\ rillo1796@gmail.com dan yohanna.ariesta@gmail.com \\ Program Studi Teknik Sipil, Fakultas Teknik \\ Universitas Katolik Soegijapranata, Semarang
}

\begin{abstract}
Precast material is a user-friendly construction product. One innovation that is being developed is sandwich concrete. Sandwich concrete is composed by skin layers, that are strong and stiff, and lightweight concrete as core layer. As a part of builiding construction, each structural and non-structural element resists load in certain time. The purpose of this research is to investigate creep performance of concrete sandwich beam. By observing the effect of creep, it can be known the long-term effect due to the constant loading on a material. The test specimen is formed of sandwich construction beam, with its core layer consists of lightweight concrete and styrofoam (cement EPS sandwich panel) mixture.

This research conducted with two kinds of size and proportions of specimen, single beam (length=100 cm; width=20 cm; thickness=7,5 cm) and double beam (length=100 cm; width $=20 \mathrm{~cm}$; thickness $=7,5 \mathrm{~cm}$ ) which is a combination of single beams glued together with Sikabond. The loading method that used in this research is third point loading as described on ASTM C393 in two positions, horizontally and vertically. After having loaded of $3 \mathrm{kN}$ in 2 hours, each test specimen has deflected and gives creep strain value. The values of creep strain are: specimen $\mathrm{RH}-\mathrm{SO}$ - by 3,23\%, specimen $\mathrm{RV}-\mathrm{SO} 3$ by 0,40\%, specimen $\mathrm{RH}-\mathrm{D} 03$ by 0,60\%, dan specimen $R V-D 02$ by 0,32\%. The smallest value of creep strain obtained by double beam that was tested vertically, due to have greater EI value than the horizontally tested specimens. According to the maximum deflection and load that can be resisted by the specimens, sandwich concrete shall not be recommended for structural beam. This research shows that the creep effect of constant loading by $3 \mathrm{kN}$ for 2 hours on sandwich concrete beam is not secure.
\end{abstract}

Keywords : sandwich concrete, creep, styrofoam, deflection, cement EPS sandwich panel 


\subsubsection{Pendahuluan}

Kebutuhan akan beton saat ini dapat dikatakan cukup tinggi. Hal ini dibuktikan dengan pesatnya pembangunan di bidang konstruksi guna memenuhi kebutuhan manusia di berbagai sektor kehidupan. Namun seperti yang telah diketahui, bahwa biaya untuk produksi beton murni terbilang cukup tinggi. Tak hanya itu saja, kegiatan produksi beton murni dapat menyebabkan kerugian pada beberapa hal. Misalnya limbah yang dihasilkan dapat mencemari lingkungan, sehingga menghambat segala aktivitas komponenkomponen yang berada di sekitarnya. Hal ini mendorong para akademisi dan praktisi berlomba menciptakan inovasiinovasi beton yang lebih menghemat biaya, mudah dan ramah lingkungan. Salah satunya inovasi yang saat ini sedang dalam penelitian yaitu sandwich concrete (beton berlapis). Robert $\mathrm{M}$. Jones , pada bukunya yang berjudul Mechanics of Composite Materials Second Edition (1999) menyatakan bahwa beton sandwich merupakan gabungan antara 2 (dua) material yaitu bagian kulitnya berupa material yang kuat dan kaku serta beton ringan sebagai lapisan inti (Firdaus, 2013). Pada bagian tengah penampang beton sandwich ini digunakan beton ringan yang mempunyai kekuatan rendah dan bobot yang ringan. Meningkatnya produktivitas di bidang konstruksi saat ini perlu diimbangi dengan proses pelaksanaan pembangunan yang efektif dan efisien. Salah satu metode yang cukup dipercaya dan banyak digunakan untuk meminimalisir biaya dan waktu adalah penggunaan material precast.

Material precast banyak digunakan untuk bagian-bagian non-struktural, misalnya seperti dinding. Material precast yang digunakan untuk pengganti pasangan bata merah, biasanya berbentuk panel dalam hal ini bisa berupa panel komposit atau panel sandwich, yang akan dibahas lebih lanjut.

Saat ini sedang diadakan penelitian mengenai sandwich concrete isian styrofoam yang akan diuji kekuatannya untuk mengetahui apakah material tersebut memungkinkan digunakan menjadi material pada bagian struktural misalnya balok bangunan. Selain itu, dari angka-angka yang didapat, dapat dianalisis juga kemampuan material tersebut untuk dijadikan bearing wall. Beton ringan yang digunakan adalah expanded polystyrene (EPS) cement. Masalah yang biasanya timbul dalam pembuatan beton sandwich ini adalah kelekatan material satu dengan yang lain. Hal ini dapat mempengaruhi kinerja dari beton sandwich sendiri. Salah satunya yaitu kinerja rangkak dari beton itu sendiri. Seperti yang telah diketahui kelemahan dari beton ringan sendiri yaitu kekakuan yang rendah dan rangkak yang besar. Maka dari itu, penempatan beton ini harus pada tujuan dan posisi yang tepat.

Penelitian ini merupakan bagian dari penelitian payung Susilorini dan Widianto (2018), "Inovasi Teknologi Beton Sandwich dengan Isian Styrofoam" yang didanai oleh PT Indostar Modular Sentral Semarang. Perusahaan ini merupakan perusahaan produksi rumah modular, yaitu rumah prefabrikasi yang didesain secara khusus agar dapat dibangun lebih cepat dibandingkan dengan metode konstruksi yang konvensional. 


\subsubsection{Tinjauan Pustaka}

\subsection{Rangkak}

Beton akan mengalami perubahan bentuk sebagai akibat dari pemberian beban konstan dalam jangka waktu tertentu dan biasanya cukup lama. Fenomena ini ditemukan oleh Hatt pada tahun 1907, yang kemudian dikenal dengan istilah rangkak (Nasser, 1975). Untuk mengukur rangkak dari beton dilakukan percobaan dengan memakai contoh beton dalam kondisi temperatur dan kelembaban konstan serta diberi pembebanan tetap (Neville, 1981). Rangkak dapat didefinisikan sebagai regangan tambahan yang tergantung waktu pada pembebanan tetap. Regangan rangkak ini ternyata beberapa kali lebih besar dari regangan elastis mula-mula dan kecepatan rangkak yang timbul berkurang besarnya menurut waktu. Struktur dibebani dengan besar beban yang bertahap sampai mencapai tegangan batas, beban yang diberikan ini disebut Instantaneous Loading. Pada saat tegangan yang terjadi masih berada dalam batas elastis akan terjadi deformasi elastis. Bila tegangan yang terjadi lebin besar dari tegangan elastis maka akan terjadi deformasi inelastis. Bila instantaneous loading dibiarkan sejalan dengan waktu maka akan menjadi Sustained Loading (pembebanan tetap). Akibat sustained loading ini regangan akan bertambah sejalan dengan waktu juga, pertambahan regangan di daerah elastis ini disebut creep deformation.

Besarnya deformasi rangkak sebanding dengan besarnya beban yang ditahan dan jangka waktu pembebanan (Dipohusodo, 1999). Nilai rangkak dapat diketahui dengan cara mengurangkan total deformasi yang terjadi dengan besarnya susut. Hal ini dikarenakan total deformasi yang terjadi merupakan kombinasi dari nilai rangkak dan shrinkage (Kristiawan, 2002). Rangkak, atau aliran geser material adalah peningkatan regangan terhadap waktu akibat beban yang terus menerus bekerja. Deformasi awal akibat beban adalah regangan elastis, sementara regangan tambahan akibat beban yang sama dan terus bekerja adalah regangan rangkak.

Proses awal perubahan panjang (deformasi) akibat adanya pembebanan merupakan sesuatu yang menarik utuk diketahui. Mekanisme terjadinya rangkak pada suatu mortar hampir sama dengan mekanisme terjadinya susut. Hanya saja pada susut perubahan panjang yang terjadi diakibatkan karena kehilangan air akibat hidrasi maupun penguapan atau evaporasi, sedangkan pada rangkak perubahan panjang yang terjadi diakibatkan karena adanya pembebanan. Pada suatu struktur, adanya pembebanan tersebut akan mengakibatkan air yang ada pada mortar akan terdesak untuk keluar dan pada pori-pori yang semula diisi air akan kosong. Kemudian pori-pori ini akan diisi oleh partikel lain seperti semen atau pasir. Akibatnya akan terjadi pemadatan pada mortar sebab partikel-partikel yang ada akan didesak untuk mengisi pori-pori pada mortar yang telah kosong akibat keluarnya air. Hal ini akan mengakibatkan terjadinya perubahan panjang pada mortar atau 
yang disebut rangkak. Dengan melihat hubungan antara tegangan yang diberikan $(\square)$ dan waktu $(t)$ sekaligus hubungan antara regangan $(\square)$ dan waktu (t) (pada Gambar 1), bahwa akibat terjadinya creep maka regangan akan bertambah besar dengan intensitas pertambahan regangan yang semakin berkurang seiring pertambahan waktu.
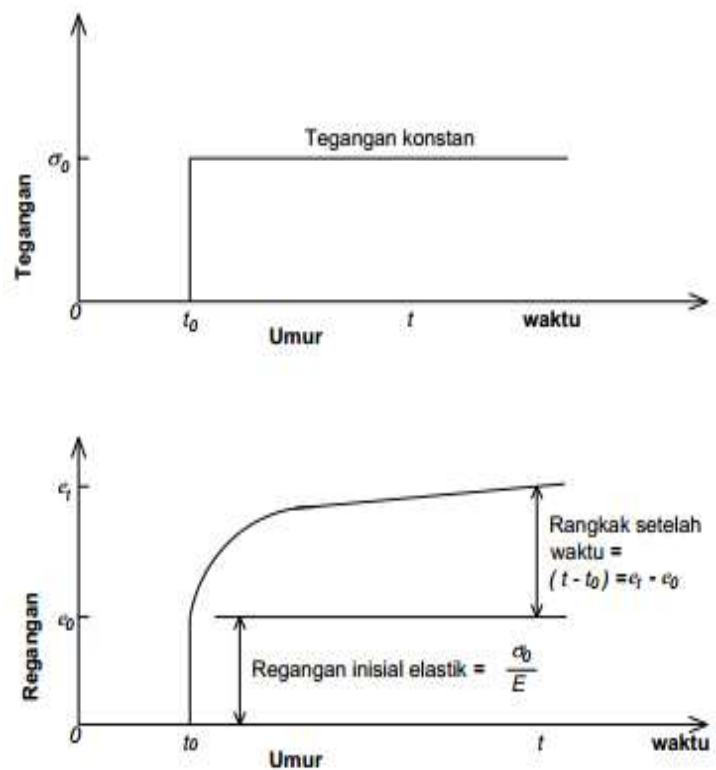

Gambar 1. Rangkak yang Terjadi Akibat Beban Konstan.

(Sumber: Samuri, 2010)

\subsection{Beton Sandwich}

Struktur sandwich merupakan struktur yang terdiri dari dua lapisan tipis, kaku dan kuat dari material padat yang dipisahkan oleh satu lapisan tebal yang terbuat dari material dengan berat jenis yang rendah, yang memiliki kekakuan dan kekuatan yang lebih rendah dari lapisan pengapitnya (Callister, 2007). Dua lapisan tipis yang terdapat pada struktur sandwich ini disebut dengan lapisan kulit, dan satu lapisan tengah disebut dengan lapisan inti (Gambar 2.3). Pada kebanyakan kasus, sebuah struktur sandwich yang efisien didapat bila berat inti dari sandwich kira-kira sama dengan jumlah berat lapisan pengapitnya. Pada umumnya lapisan kulit berupa beton normal yang mempunyai kekakuan yang tinggi. Sedangkan pada lapisan inti berupa beton ringan yang memiliki kekakuan rendah, namun memiliki kinerja rangkak yang tinggi (Firdaus, 2013).

Bahan struktur sandwich merupakan gabungan keunggulan kekuatan dan kekakuan dari lapisan beton kulit dengan massa dari lapisan beton inti yang rendah. Hasilnya adalah suatu struktur yang lebih ringan tetapi kuat dan kaku (Jones, 1999).

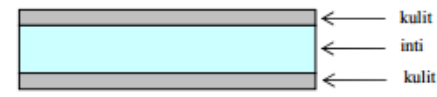

Gambar 2. Struktur Beton Sandwich (Sumber: Firdaus, 2003)

\subsection{Beton Ringan}

Dalam beberapa jenis beton, kita mengenal adanya beton ringan. Beton ringan adalah beton yang umumnya terbuat dari agregat ringan, di mana agregat ringan ini adalah agregat dengan berat isi kering oven gembur maksimum $1100 \mathrm{~kg} / \mathrm{m} 3$. Berat isi beton ringan berkisar antara $1360-1840 \mathrm{~kg} / \mathrm{m} 3$ dan dapat dianggap sebagai batas dari beton ringan yang sebenarnya, meskipun nilai ini kadang-kadang melebihi (Suamita, 2012). Menurut SNI 03-3449-1994 beton ringan struktural adalah beton yang memakai agregat ringan atau campuran agregat kasar ringan dan pasir alam sebagai pengganti 
agregat halus ringan dengan ketentuan tidak boleh melampaui berat isi maksimum beton 1850 $\mathrm{kg} / \mathrm{m} 3$ dan harus memenuhi ketentuan kuat tekan dan kuat tarik belah beton ringan untuk tujuan struktural. Kekuatan tarik dari beton ringan yang kering udara berkisar antara $70 \%$ sampai $90 \%$ dari kuat tarik beton normal dengan kekuatan tekan yang sama, sedang apabila kedua jenis beton tersebut secara terus menerus diberikan kelembaban maka kekuatan tariknya mempunyai nilai besar yang hampir sama.

\subsection{Cement Expanded Polystyrene (EPS) Sandwich Panel}

Salah satu perkembangan di dunia material konstruksi yang menggunakan EPS adalah beton bertulang. Pada dasarnya, material ini merupakan panel komposit yang terdiri atas dua lapis beton bertulang yang di desain dengan lapisan tengahnya terdiri atas expanded polysytrene dalam hal ini styrofoam dan bagian kulitnya merupakan fiber cement.

Salah satu contoh EPS Sandwich Panel yang sudah diproduksi dan dipasarkan di Indonesia beberapa tahun terakhir adalah b-panel. Fungsi lapisan EPS adalah untuk menahan suhu dan kelembapan, dan sebagai pereduksi kerapatan dinding. Selain itu lapisan EPS juga dapat digunakan sebagai bekisting pada saat proses coating beton.

Sebagai contoh, pada b-panel, lapisan EPS yang bergelombang memungkinkan terbentuknya kolom kecil yang berhubungan antar dinding. Pada lapisan EPS dengan gelombang searah, terdapat kawat baja dengan tegangan tarik yang tinggi. Hal ini menyebabkan panel dinding sandwich EPS menjadi sangat kuat dan bisa menjadi bagian dari struktur penopang beban (IAIMagazine, 2009).

Penggunaan panel sandwich EPS dapat mengurangi jumlah dan ukuran balok maupun kolom, bahkan menghilangkannya. Misalnya sebuah ruangan dengan bentang balok 6 meter, tidak perlu diberikan kolom praktis. Keuntungan penggunaannya adalah menghemat waktu dan biaya, dalam hal ini pembuatan struktur kolom dan balok, dan juga mengurangi beban statis struktur. Coating yang dilakukan adalah dengan penyemprotan pada panel EPS yang sudah terpasang dan bentuknya seragam (struktur yang monoton). Karakteristik ini yang menyebabkan bangunan dari panel sandwich EPS cenderung tahan terhadap gempa. Dinding dengan panel sandwich EPS memiliki konduktivitas termal sebesar $10 \%$ dibandingkan dengan dinding konvensional (bata merah dan plesteran) dengan ketebalan yang sama (IAIMagazine, 2009).

\subsection{Styrofoam}

Styrofoam yang memiliki nama lain polystyrene, begitu banyak digunakan oleh manusia dalam kehidupannya sehari hari. Begitu styrofoam diciptakan pun langsung marak digunakan di Indonesia. Styrofoam pada umumnya digunakan sebagai pembungkus barang elektronik dan makanan karena sifatnya yang tidak mudah bocor, praktis dan ringan. 
Polystyrene ini dihasilkan dari styrene (C6H5CH9CH2) yang mempunyai gugus phenyl yang tersusun secara tidak teratur sepanjang garis karbon dari molekul. Styrofoam ini memiliki berat jenis sampai $1050 \mathrm{~kg} / \mathrm{m} 3$, kuat tarik sampai $40 \mathrm{MN} / \mathrm{m} 2$, dan modulus lentur sampai $3 \mathrm{GN} / \mathrm{m} 2$, modulus geser sampai $0,99 \mathrm{GN} / \mathrm{m} 2$, angka poison 0,33 (Dharma Giri et.al, 2008). Dalam bentuk butiran (granular) expanded polystyrene mempunyai berat satuan sangat kecil yaitu $13-22 \mathrm{~kg} / \mathrm{m} 3$. Sehingga expanded polystyrene dalam campuran beton sangat cocok digunakan untuk mendapatkan berat jenis beton yang ringan. Penggunaan styrofoam dalam beton dapat dianggap sebagai rongga udara. Namun keuntungan menggunakan styrofoam dibandingkan dengan rongga udara dalam beton berongga adalah styrofoam mempunyai kuat tarik. Kerapatan atau berat jenis beton dengan campuran styrofoam dapat diatur dengan mengontrol jumlah campuran styrofoam dalam beton (Dharma Giri et.al, 2008).

\subsubsection{Metode Penelitian}

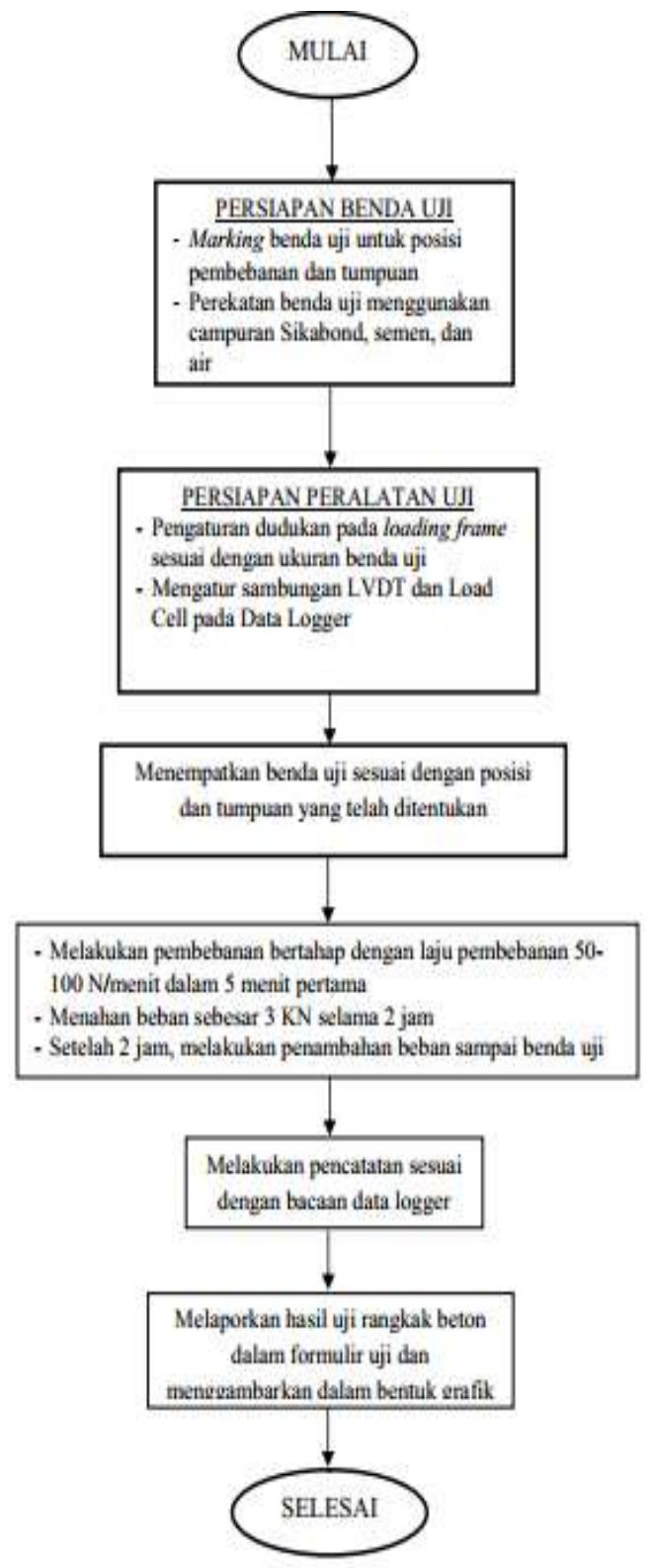

Gambar 3. Diagram Alir Penelitian.

Penelitian ini menggunakan dua tipe benda uji balok beton sandwich. Tipe yang pertama adalah balok tunggal. Balok tunggal memiliki dimensi panjang $(p)=100 \mathrm{~cm}$, lebar $(1)=20 \mathrm{~cm}$, dan tebal (t) $=7,5 \mathrm{~cm}$. Tipe yang kedua adalah balok ganda. Balok ganda terdiri atas dua balok tunggal yang saling direkatkan sisi panjangnya. 
Benda uji merupakan balok sandwich yang terdiri atas dua lapisan yaitu lapisan kulit (facing) dan lapisan inti (core) seperti yang ditunjukkan pada Gambar 3.4 .

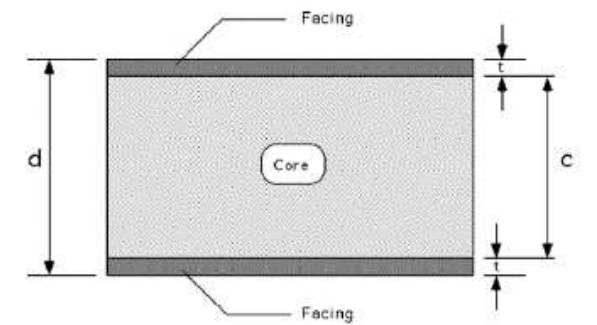

Gambar 4. Dimensi Ketebalan Struktur Sandwich. (Sumber: ASTM C393/C393M)

Pengujian rangkak dalam penelitian ini mengacu pada standar ASTM C480/C480M tentang Standard Test Method for Flexure Creep of Sandwich Constructions. Dalam acuan ini disebutkan bahwa rangkaian peralatan sistem pembebanan terhadap benda uji dapat menyesuaikan mekanisme yang tertulis pada ASTM C393/C393M tentang Standard Test Method for Core Shear Properties of Sandwich Constructions by Beam Flexure, namun pengaplikasian beban terhadap benda uji rangkak adalah beban yang konstan. Sistem pembebanan yang digunakan dalam penelitian ini adalah third point loading seperti yang ditunjukkan pada Gambar 5.

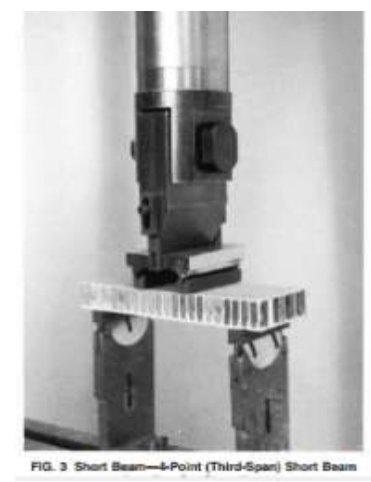

Gambar 5. Sistem Pembebanan Third Point Loading sesuai ASTM C393/C393M.

\subsection{Prosedur Pengujian}

Langkah-langkah pengujian rangkak pada balok beton sandwich adalah sebagai berikut:

a. Mempersiapkan loading frame yang akan digunakan untuk pengujian rangkak.

b. Mengatur dudukan pada loading frame sehingga sesuai dengan dimensi benda uji.

c. Meletakkan benda uji pada tumpuan dan atur posisi benda uji sehingga siap untuk pengujian.

d. Meletakkan tumpuan beban di atas benda uji sebagai third point loading yang merupakan sistem pembebanan balok yang digunakan pada penelitian ini.

e. Mengatur posisi load cell dan penyangga load cell sehingga beban dapat ditransfer ke benda uji secara maksimal. Penyangga yang digunakan adalah beton mortar dan beberapa pelat baja. Berat dari masing-masing penyangga ini nantinya akan diakumulasikan pada pembacaan load cell sebagai beban maksimum yang dapat ditahan benda uji.

f. Mempersiapkan data logger dan menyesuaikan dengan sensor LVDT serta load cell supaya pembacaan berada pada kondisi netral $(0,0)$.

g. Memulai percobaan dengan pemberian beban dengan laju pembebanan 50-100 N per menit. Penambahan beban dilakukan secara manual menggunakan tuas hidrolik yang terkoneksi dengan load cell dan loading frame. Benda uji diberikan pembebanan bertahap dengan laju 
pembebanan $50-100 \mathrm{~N}$ per menit pada 10 menit pertama. Penambahan beban dilakukan secara manual menggunakan tuas hidrolik. Kemudian benda uji diberikan beban konstan sebesar $3 \mathrm{kN}$ selama dua jam. Setelah dua jam, penambahan beban dilakukan dengan kenaikan 100 $\mathrm{N}$ per menit sampai benda uji patah.

h. Menghentikan pembebanan setelah benda uji patah dan mengecek pembacaan data pada data logger.

\subsubsection{Hasil dan Pembahasan}

Pengujian kinerja rangkak pada balok beton sandwich dilakukan terhadap sejumlah benda uji dengan pembebanan yang bekerja arah transversal. Benda uji yang digunakan ada dua tipe yaitu balok tunggal dan balok ganda. Benda uji diletakkan secara horizontal dan vertikal untuk mengetahui pengaruh lendutan akibat pembebanan. Dalam penelitian ini, jumlah duplikasi yang digunakan untuk masing-masing tipe benda uji adalah tiga sampel.

Benda uji telah diberi kode masingmasing untuk mempermudah pencatatan dan analisis data. Benda uji yang berupa balok tunggal dengan posisi pengujian horizontal diberi kode RH-S diikuti nomor urut benda uji. Benda uji yang berupa balok ganda dengan posisi pengujian horizontal diberi kode RH-D diikuti nomor urut benda uji. Benda uji yang berupa balok tunggal dengan posisi pengujian vertikal diberi kode RV-S diikuti nomor urut benda uji. Benda uji yang berupa balok ganda dengan posisi pengujian vertikal diberi kode RV-D diikuti nomor urut benda uji.
Data lendutan yang diperoleh dari bacaan data logger memiliki range yang cukup besar karena pembacaan dilakukan secara otomatis setiap dua detik. Oleh karena itu, data hasil penelitian disajikan dalam bentuk grafik.

\subsection{Analisis Pengujian Rangkak Balok Tunggal}

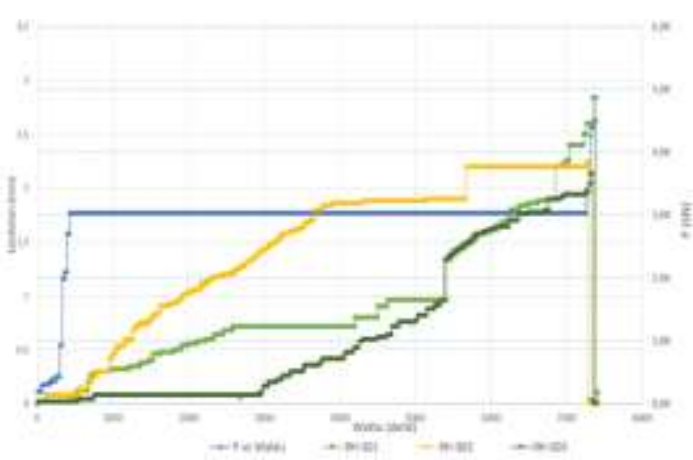

Gambar 6. Hubungan Lendutan (mm) dan Waktu (detik) Benda Uji Balok Tunggal Horizontal.

Gambar 6 menunjukkan hubungan antara lendutan yang terjadi pada ketiga benda uji tipe balok tunggal yang diuji dalam posisi horizontal terhadap waktu pengujian. Pada beberapa menit awal, benda uji dibebani beban secara bertahap dengan laju pembebanan 50-100 $\mathrm{N}$ per menit. Pertambahan beban ini dilakukan hingga benda uji mulai menunjukkan perubahan lendutan. Beban konstan sebesar $3 \mathrm{kN}$ yang dikenakan pada benda uji secara konstan selama dua jam mengakibatkan benda uji mengalami perubahan lendutan. Pada Gambar 6 diketahui bahwa benda uji RH-S03 mengalami perubahan lendutan yang cenderung lebih kecil dibandingkan dengan kedua benda uji lainnya sampai dengan menit ke-50. Selama beban konstan $3 \mathrm{kN}$ bekerja selama 2 jam 
terhadap masing-masing sampel, benda uji RH-S02 menunjukkan perubahan lendutan yang cukup cepat dan cukup signifikan. Setelah dua jam, beban yang dikenakan pada benda uji ditingkatkan setiap $100 \mathrm{~N}$ untuk mencapai beban maksimum yang mampu ditahan dan lendutan maksimum yang dialami oleh benda uji. Dari ketiga sampel, benda uji RH-S01 mengalami lendutan yang paling besar dan mampu menahan beban lebih besar dibandingkan dua sampel lainnya yang diberi perlakuan sama.

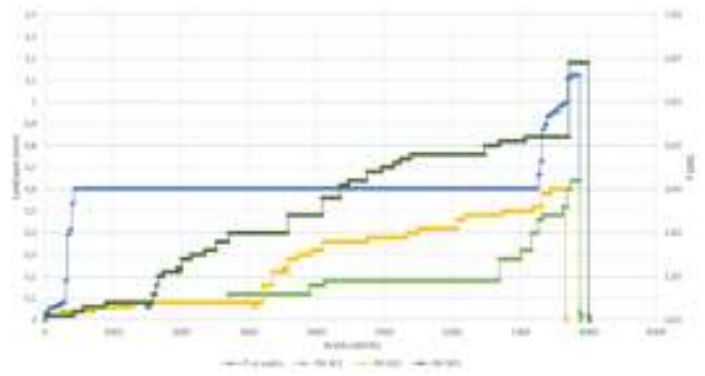

Gambar 7. Hubungan Lendutan (mm) dan Waktu (detik) Benda Uji Balok Tunggal Vertikal.

Gambar 7 menunjukkan hubungan antara lendutan yang terjadi pada ketiga benda uji tipe balok tunggal yang diuji dalam posisi vertikal terhadap waktu pengujian. Pada beberapa menit awal, benda uji dibebani beban secara bertahap dengan laju pembebanan 50-100 N per menit. Pertambahan beban ini dilakukan hingga benda uji mulai menunjukkan perubahan lendutan. Beban konstan sebesar $3 \mathrm{kN}$ yang dikenakan pada benda uji secara konstan selama dua jam mengakibatkan benda uji mengalami perubahan lendutan. Pada Gambar 7 diketahui bahwa benda uji RV-S01 mengalami perubahan lendutan yang cenderung lebih kecil dibandingkan dengan kedua benda uji lainnya sampai dengan menit ke-65. Selama beban konstan $3 \mathrm{kN}$ bekerja selama 2 jam terhadap masing-masing sampel, benda uji RV-S03 menunjukkan perubahan lendutan yang cukup cepat dan cukup signifikan.

\subsection{Pengujian Rangkak Balok Ganda}

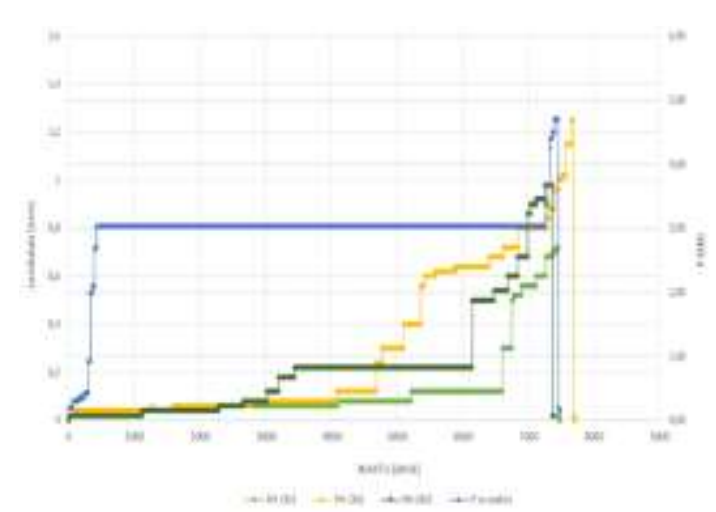

Gambar 8. Hubungan Lendutan (mm) dan Waktu (detik) Benda Uji Balok Ganda Horizontal.

Gambar 8 menunjukkan hubungan antara lendutan yang terjadi pada ketiga benda uji tipe balok ganda yang diuji dalam posisi horizontal terhadap waktu pengujian. Pada beberapa menit awal, benda uji dibebani beban secara bertahap dengan laju pembebanan 50-100 N per menit. Pertambahan beban ini dilakukan hingga benda uji mulai menunjukkan perubahan lendutan. Beban konstan sebesar $3 \mathrm{kN}$ yang dikenakan pada benda uji secara konstan selama dua jam mengakibatkan benda uji mengalami perubahan lendutan. Pada Gambar 8 diketahui bahwa 
ketiga benda uji mengalami perubahan lendutan yang cenderung kecil sampai dengan menit ke-50. Selama beban konstan $3 \mathrm{kN}$ bekerja selama 2 jam terhadap masingmasing sampel, ketiga benda uji menunjukkan respon perubahan lendutan yang cenderung sama dalam arti bertambah terhadap waktu. Benda uji RH-D02 mengalami lendutan lebih besar dibandingkan dengan kedua benda uji lainnya selama pembebanan konstan.

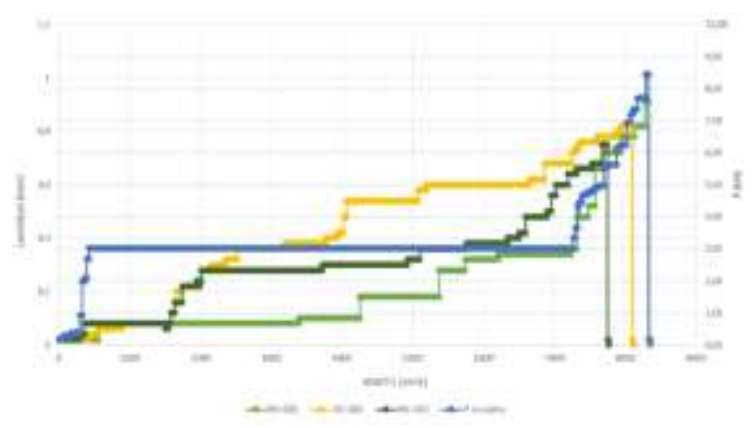

Gambar 9. Hubungan Lendutan (mm) dan Waktu (detik) Benda Uji Balok Ganda Vertikal.

Gambar 9 menunjukkan hubungan antara lendutan yang terjadi pada ketiga benda uji tipe balok ganda yang diuji dalam posisi vertikal terhadap waktu pengujian. Pada beberapa menit awal, benda uji dibebani beban secara bertahap dengan laju pembebanan 50-100 N per menit. Pertambahan beban ini dilakukan hingga benda uji mulai menunjukkan perubahan lendutan. Beban konstan sebesar $3 \mathrm{kN}$ yang dikenakan pada benda uji secara konstan selama dua jam mengakibatkan benda uji mengalami perubahan lendutan. Pada Gambar 9 diketahui bahwa ketiga benda uji mengalami perubahan lendutan yang cenderung kecil sampai dengan menit ke-25. Selama beban konstan $3 \mathrm{kN}$ bekerja selama 2 jam terhadap masingmasing sampel, ketiga benda uji menunjukkan respon perubahan lendutan yang cenderung sama dalam arti bertambah terhadap waktu dan cukup besar. Benda uji RV-D02 mengalami lendutan lebih besar dibandingkan dengan kedua benda uji lainnya selama pembebanan konstan.

Dari data dan grafik yang sudah dihasilkan dari pengujian rangkak, maka dapat diperoleh pula persentase perubahan lendutan pada benda uji yang diberikan beban konstan $3 \mathrm{kN}$ selama 2 jam. Perhitungan persentase lendutan masing-masing benda uji diperoleh dari perbandingan antara selisih lendutan yang terjadi selama dua jam terhadap ketebalan awal masing-masing benda uji. Untuk benda uji balok tunggal yang diuji dalam posisi horizontal, didapatkan prosentase perubahan lendutan sebagai berikut: benda uji RH-S01 sebesar 3,23\%, benda uji RH-S02 sebesar 2,83\%, dan benda uji RHS03 sebesar 2,56\%. Untuk benda uji balok ganda yang diuji dalam posisi horizontal, diperoleh prosentase sebagai berikut: benda uji RH-D01 sebesar $0,37 \%$, benda uji RH-D02 sebesar $0,51 \%$, dan benda uji RHD03 sebesar 0,60\%. Untuk benda uji balok tunggal yang diuji dalam posisi vertikal diperoleh prosentase perubahan lendutan sebagai berikut: benda uji RV-S01 sebesar 0,18\%, benda uji RV-S02 sebesar 0,24\%, dan benda uji RV-S03 sebesar $0,40 \%$. Untuk benda uji balok ganda yang diuji dalam posisi vertikal diperoleh prosentase lendutan 
sebagai berikut: benda uji RV-D01 sebesar $0,17 \%$, benda uji RV-D02 sebesar 0,32\%, dan benda uji RVD03 sebesar 0,23\%. Dari data-data tersebut dapat diketahui bahwa perubahan lendutan yang relatif kecil ada pada benda uji yang diuji dalam posisi vertikal. Maka dapat dikatakan bahwa rangkak yang terjadi pada benda uji dengan posisi vertikal nilainya kecil. Dengan mempertimbangkan beban maksimum yang dapat ditahan dan lendutan maksimum yang dialami benda uji, maka benda uji balok ganda yang diuji secara vertikal memiliki kekuatan yang lebih besar dibandingkan dengan benda uji tipe lainnya. Benda uji balok ganda yang diuji secara vertikal mampu menahan beban lebih besar dan lendutan maksimum yang terjadi lebih kecil dibandingkan benda uji lainnya.

\subsection{Hasil Pengamatan}

Benda uji mengalami retak hingga patah selama proses pengujian yang dilakukan dalam penelitian ini. Kerusakan masingmasing benda uji terjadi setelah mencapai beban maksimum. Benda uji tidak memiliki tulangan sehingga meskipun kerusakan ditandai dengan muncul retakan, benda uji patah secara tiba-tiba.

\subsubsection{Pola Retak Balok Tunggal Horizontal}

Benda uji RH-S01 mengalami patah setelah mencapai beban maksimum 4,50 $\mathrm{kN}$ dalam waktu pengujian selama 2 jam 3 menit 4 detik. Titik patah pada benda uji RH-S01 terletak pada $41 \mathrm{~cm}$ dari kiri dan $59 \mathrm{~cm}$ dari kanan dan ditunjukkan pada Gambar 10.

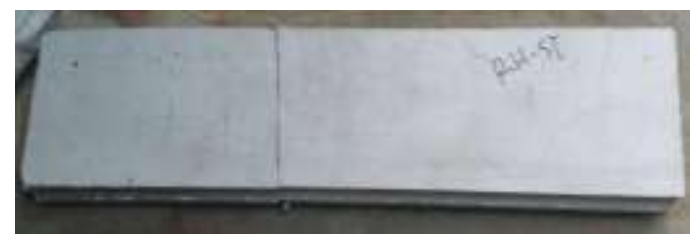

Gambar 10. Tampak Atas Benda Uji RH-S01 Setelah Pengujian.

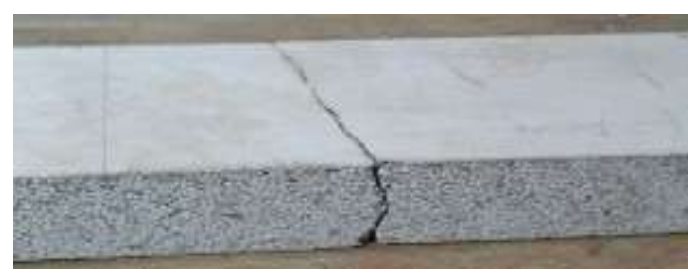

Gambar 11. Patah yang Terjadi pada Benda Uji RH-S01.

\subsubsection{Pola Retak Balok Tunggal Vertikal}

Benda uji RV-S01 mengalami patah setelah mencapai beban maksimum 5,62 $\mathrm{kN}$ dalam waktu pengujian selama 2 jam 11 menit 40 detik. Titik patah pada benda uji RV-S01 terletak pada $42 \mathrm{~cm}$ dari kiri dan $58 \mathrm{~cm}$ dari kanan dan ditunjukkan pada Gambar 12.

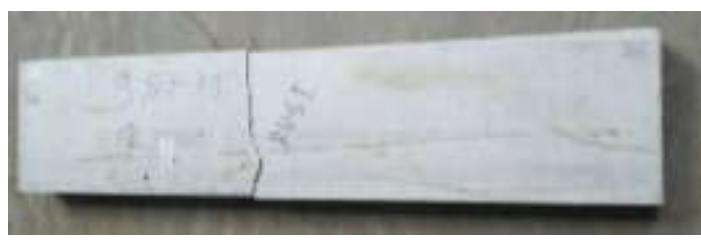

Gambar 12. Tampak Atas Benda Uji RV-S01 Setelah Pengujian.

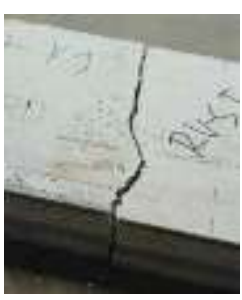

Gambar 13. Patah yang Terjadi pada Benda Uji RV-S01. 


\subsubsection{Pola Retak Balok Ganda Horizontal}

Benda uji RH-D02 mengalami patah setelah mencapai beban maksimum 4,70 $\mathrm{kN}$ dalam waktu pengujian selama 2 jam 34 menit 36 detik. Titik patah pada benda uji RH-D02 terletak pada $51,5 \mathrm{~cm}$ dari kiri dan 48,5 $\mathrm{cm}$ dari kanan dan ditunjukkan pada Gambar 14.

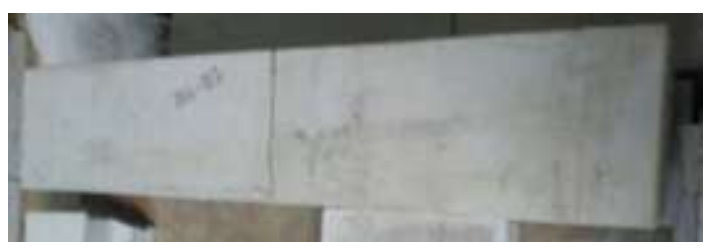

Gambar 14. Tampak Atas Benda Uji RH-D02 Setelah Pengujian.

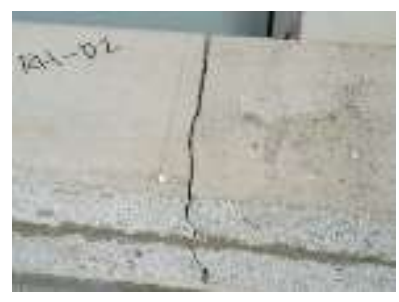

Gambar 15. Patah yang Terjadi pada Benda Uji RH-D02.

\subsubsection{Pola Retak Balok Ganda Vertikal}

Benda uji RV-D01 mengalami patah setelah mencapai beban maksimum 8,46 $\mathrm{kN}$ dalam waktu pengujian selama 2 jam 49 menit 19 detik. Titik patah pada benda uji RV-D01 terletak pada $36 \mathrm{~cm}$ dari kiri dan $64 \mathrm{~cm}$ dari kanan dan ditunjukkan pada Gambar 16.

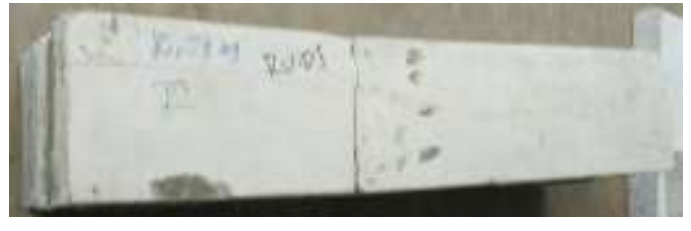

Gambar 16. Tampak Atas Benda Uji RV-D01 Setelah Pengujian.

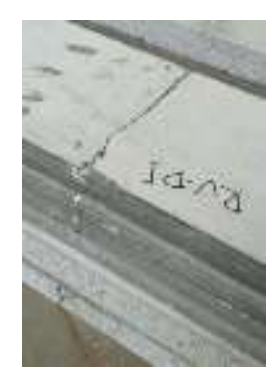

Gambar 17. Patah yang Terjadi pada Benda Uji RV-D01.

\section{Kesimpulan dan Saran}

\subsection{Kesimpulan}

Dari pengujian rangkak yang dilakukan terhadap seluruh benda uji, maka dapat disimpulkan beberapa hal sebagai berikut:

a) Pada balok beton sandwich tunggal, perubahan lendutan yang lebih signifikan adalah pada benda uji yang diuji dengan posisi horizontal. Pada benda uji yang diuji secara horizontal, lendutan yang dialami lebih dari 2 $\mathrm{mm}$.

b) Pada balok beton sandwich ganda, tidak ada perbedaan yang signifikan dari data perubahan lendutan yang dihasilkan, baik jika diuji secara horizontal maupun diuji secara vertikal. Lendutan yang dialami oleh benda uji balok ganda yang diuji secara horizontal maupun vertikal adalah berkisar $1 \mathrm{~mm}$ hingga benda uji patah. 
c) Pada balok beton sandwich tunggal yang diuji dalam posisi horizontal, peristiwa rangkak tampak selama dua jam pembebanan konstan sebesar 3 $\mathrm{kN}$. Benda uji mengalami perubahan lendutan tanpa adanya penambahan beban. Perubahan lendutan yang paling signifikan adalah pada benda uji RH-S01 yaitu $0,08 \mathrm{~mm}$ sampai 2,5 $\mathrm{mm}$, atau bertambah sebesar 3,23\% terhadap ketebalan awal benda uji $(\mathrm{t}=$ $75 \mathrm{~mm}$ ).

d) Pada balok beton sandwich tunggal yang diuji dalam posisi vertikal, peristiwa rangkak tampak selama dua jam pembebanan konstan sebesar 3 $\mathrm{kN}$. Benda uji mengalami perubahan lendutan tanpa adanya penambahan beban. Perubahan lendutan yang paling signifikan adalah pada benda uji RV-S03 yaitu 0,04 mm sampai $0,84 \mathrm{~mm}$, atau bertambah sebesar $0,40 \%$ terhadap ketebalan awal benda uji $(\mathrm{t}=200 \mathrm{~mm})$.

e) Pada balok beton sandwich ganda yang diuji dalam posisi horizontal, peristiwa rangkak tampak selama dua jam pembebanan konstan sebesar 3 $\mathrm{kN}$. Benda uji mengalami perubahan lendutan tanpa adanya penambahan beban. Perubahan lendutan yang paling signifikan adalah pada benda uji RH-D03 yaitu $0,02 \mathrm{~mm}$ sampai $0,92 \mathrm{~mm}$, atau bertambah sebesar $0,60 \%$ terhadap ketebalan awal $(\mathrm{t}=$ $150 \mathrm{~mm})$.

f) Pada balok beton sandwich ganda yang diuji dalam posisi vertikal, peristiwa rangkak tampak selama dua jam pembebanan konstan sebesar 3 $\mathrm{kN}$. Benda uji mengalami perubahan lendutan tanpa adanya penambahan beban. Perubahan lendutan yang paling signifikan adalah pada benda uji RV-D02 yaitu $0,04 \mathrm{~mm}$ sampai $0,68 \mathrm{~mm}$, atau bertambah sebesar
$0,32 \%$ terhadap ketebalan awal $(\mathrm{t}=$ $200 \mathrm{~mm}$ ).

g) Perubahan lendutan yang relatif kecil adalah pada benda uji yang diuji dalam posisi vertikal. Maka dapat dikatakan bahwa rangkak yang terjadi pada benda uji dengan posisi vertikal nilainya kecil. Dengan mempertimbangkan beban maksimum yang dapat ditahan dan lendutan maksimum yang dialami benda uji, maka benda uji balok ganda yang diuji secara vertikal memiliki kekuatan yang lebih besar dibandingkan dengan benda uji tipe lainnya. Benda uji balok ganda yang diuji secara vertikal mampu menahan beban lebih besar dibandingkan benda uji tipe lainnya, yaitu $5-8,5 \mathrm{kN}$. Dan lendutan maksimum yang terjadi, yaitu 0,75 - 0,91 $\mathrm{mm}$, lebih kecil dibandingkan benda uji lainnya.

\subsection{Saran}

Berdasarkan pelaksanaan dan hasil yang didapatkan dari penelitian "Kinerja Rangkak pada Balok Beton Sandwich dengan Isian Beton Ringan Campuran Styrofoam (Cement EPS Sandwich Panel), beberapa saran yang dapat disampaikan bagi penelitian-penelitian rangkak pada balok di masa yang akan datang antara lain:

a) Pada penelitian ini digunakan alat uji loading frame sistem hidrolik sebagai modifikasi mekanisme pembebanan terhadap benda-benda uji rangkak. Diharapkan untuk penelitian berikutnya dapat lebih mengacu ke ASTM C480, di mana pembebanan menggunakan lever (tuas) system.

b) Diharapkan sebelum melakukan pengujian mekanis terhadap balok beton sandwich, dilakukan penelitian material-material penyusun beton sandwich isian styrofoam. 
c) Untuk pengamatan peristiwa rangkak lebih lanjut, maka beban konstan yang digunakan untuk penelitian bisa dikurangi besarnya dengan waktu pengujian yang lebih lama sehingga dapat diketahui kecenderungan perubahan lendutan dapat diamati secara lebih detil.

d) Beton sandwich memungkinkan untuk digunakan sebagai dinding struktural dan dengan diberi sedikit beban. Namun, untuk meminimalisir kerusakan, beban yang diberikan kecil. Struktur ini mampu menahan beban sebesar $150 \mathrm{~kg}$, selebihnya ditanggung oleh balok dan kolom yang dipasang di sekeliling dinding.

\section{Daftar Pustaka}

ASTM C393/C393M. Standard Test Method for Core Shear Properties of Sandwich Constructions by Beam Flexure.

ASTM C480-99. Standard Test Method for Flexure Creep of Sandwich Constructions.

Callister, W. D. (2007). Materials Science and Engineering Seventh Edition. New York: John Wiley and Sons, Inc. Diakses pada 7 November 2017 dari https://abmpk.files.wordpress.com/ 2014/02/book_maretial-sciencecallister.pdf.

Dharma Giri, I. B., Sudarsana, I. K., \& Tutarani, N. M. (2008, Januari). "Kuat Tekan dan Modulus Elastisitas Beton dengan Penambahan Styrofoam (Styrocon")". Jurnal Ilmiah Teknik Sipil, 12, 75-85. Dipetik November 7, 2017. Diakses pada 7 Juli 2017 dari https://ojs.unud.ac.id/index.php/jits/ article/view/3480.

Dipohusodo, I. (1999). Struktur Beton Bertulang. Jakarta: Gramedia.

Firdaus. (2013). "Perilaku Elemen Beton Sandwich Terhadap Pengujian Geser Murni." Konferensi Nasional Teknik Sipil 7 (hal. 39-46). Surakarta: Universitas Sebelas Maret. Diakses pada 5 Mei 2017 dari

http://sipil.ft.uns.ac.id/konteks7/pro siding/036S.pdf.

Hongbo Zhu, C. L. (2014). "Impact Resistance of A Novel Expanded Polystrene Cement-Based Material." Journal of Wuhan University of TechnologyMater.Sci.Ed., 29, 284-290. Diakses pada 10 Juli 2017 dari https://link.springer.com/content/pd f/10.../s11595-014-0909-4.pdf.

IAIMagazine. (2009, December). "Reinforced concrete - Expanded Polystrene (EPS) Sandwich Panel." Techno Konstruksi Magazine, hal. 2-5. Diakses pada 10 Juli 2017 dari http://www.b-panel.com/2009-12reinforced-concrete-\%E2\%80\%93expanded-polystyrene-epssandwich-panelmegatrend-energyefficient-and-earth-quake-buildingmaterial.

Jones, R. M. (1999). Mechanics of Composite Materials (2nd ed.). Philadelphia: Taylor \& Francis, Inc. Diakses pada 7 November 2017 dari https://soaneemrana.org/onewebme dia/Mechanics\%20of\%20Composit e\%20Materials\%202nd\%20Ed\%20 1999\%20BY\%20\%5B Taylor\%20\& $\% 20$ Francis $\% 5 D$.pdf. 
Kristiawan, S. (2002). Restrained Shrinkage Cracking of Concrete. Inggris: School of Civil Engineering $\mathrm{PhD}$.

Nasser, S. N. (1975). “Theory of Creep and Shrinkage In Concrete Structure : A Precis of Recent Developments." (Vol. II, hal. 1-99). Illinois: Mechanics Today. Diakses pada 6 Juli 2017 dari http://www.civil.northwestern.edu/ people/bazant/PDFs/Papers/S2.pdf.

Neville, A. (1981). Properties of Concrete (5th ed.). London: Pitman. Diakses pada 3 November 2017 dari https://igitgeotech.files.wordpress.c om/2014/10/properties-of-concreteby-a-m-neville.pdf.

Samuri. (2010). "Pengaruh Rangkak terhadap Kompatibilitas Dimensional Antara Beton Normal dan Repair Material dengan Bahan Tambah Polymer." Surakarta: Universitas Sebelas Maret. Diakses pada 10 Juli 2017 dari https://eprints.uns.ac.id/8729/1/132 560608201007071.pdf.

Straalen, I. J. (1998). "Comprehensive Overview of Theories for Sandwich Panels." Workshop on Modelling of Sandwich Structures and Adhesive Bonded Joints (hal. 71-100). Porto: TNO Bouw.

Suamita, I. W. (2012). "Karakteristik Beton Ringan dengan Menggunakan Tempurung Kelapa sebagai Bahan Pengganti Agregat Kasar." Palu: Universitas Tadulako. Diakses pada 9 Juli 2017 dari https://www.academia.edu/476306 7/KARAKTERISTIK_BETON_RI NGAN_DENGAN_MENGGUNA KAN_TEMPURUNG_KELAPA_S EBAGAI_BAHAN_PENGGANTI _AGREGAT_KASAR.
Susilorini, Rr. M. I. R, Widianto, D. (2018). "Inovasi Teknologi Beton Sandwich dengan Isian Styrofoam." Laporan Akhir. Program Studi Teknik Sipil, Unika Soegijapranata.

Winter, G., \& Nilson, A. H. (1993). Perencanaan Struktur Beton Bertulang. Jakarta: PT Pradnya Paramita. 